\title{
CHEMICAL AND PHYSICO-CHEMICAL PROPERTIES OF ORANGE FLESHED SWEET POTATOES (OFSP) CHIPS DRIED USING SOLAR DYERS
}

\author{
Pessu, P. O., *Abel, G. I., Akande, S. A., Ayanda, I. S., Adarabierin, I. G., \\ Olagunju, O. D., Gbabe, E. K.
}

Nigerian Stored Products Research Institute (NSPRI) Headquarters, Km 3, Asa-Dam Road, P. M. B. 1489, Ilorin, Kwara State

Corresponding Author: igbelenspri@gmail.com

\begin{abstract}
In this study, drying technology was employed to process fresh orange fleshed sweet potatoes (OFSP) into dried slices using NSPRI improved solar tent dryer, parabolic shaped solar tent dryer in comparison with open air drying and its effect on the chemical, physico-chemical and mineral constituents of dried OFSP slices was investigated. Results showed that the dried-OFSP contained ash (3.69-4.09\%), fat (4.09-5.09\%), crude fibre (4.69-5.15\%), protein (5.87-8.28 \%), carbohydrate (78.22-82.21\%), vitamin C (8.55-20.49 $\mathrm{mg} / 100 \mathrm{~g}$ ), phenolics $(0.1-1.28 \mathrm{mg} / \mathrm{kg}$ ), flavonoids $(984-145 \mathrm{mg} / \mathrm{kg}$ ) and reducing sugar $(35.01-82.23 \mathrm{~g} / 100 \mathrm{~g})$. The total titratable acidity of the dried OFSP slices varied between $0.56-0.89 \%$, total soluble solids ranged between 5.70-7.00 'Brix while $\mathrm{pH}$ ranged between 4.94-6.47. Zinc, magnesium, potassium, calcium, sodium, iron were present in varying levels but aluminium, lead and cadmium were not detected in all the samples. This study therefore showed that good quality dried OFSP slices with appreciable nutrient content can be obtained from drying in NSPRI solar tent dryers especially with the use of the parabolic shaped solar tent dryer. Thus, the parabolic solar tent dryer is recommended for drying crops.
\end{abstract}

Keywords: Drying technology, Orange fleshed sweet potato, NSPRI solar dyers, Physicochemical properties 


\section{INTRODUCTION}

Root and tuber crops such as yam, cassava, cocoyam and potato provide food and income to many households in Nigeria. They are second only in importance to cereals as a global source of carbohydrates. They are rich sources of carbohydrates, crude fibre and energy as well as some minerals and essential vitamins (Oladipo et al., 2017). Roots and tubers are referred to as 'perishable' crops. One major problem with perishable crops such as roots and tubers is that they deteriorate very quickly after harvest due to high moisture, resulting in tremendous quantitative and qualitative losses after harvest. According to the Commercial Cooperation of the Organization of the Islamic Cooperation (COMCEC) Coordination Office (2016), postharvest losses of roots and tubers in sub-Saharan Africa is about $28 \%$ in quantity with economic losses reported in Nigeria being USD20 (in South-West Nigeria only) (Naziri et al., 2015).

Fresh roots and tubers can be preserved by the application of different preservation techniques such as freezing, application of heat, chemical method, physical method and drying (Morris et al., 2004).

Drying of agriculture produce is the oldest and widely used preservation method. It involves reduction of water from foods to control enzyme and microbial activities and thus reduce spoilage and losses. Drying of foods is carried out primarily to ensure stability of the product quality for a given storage period or to ensure product availability in off-season. The process of drying lowers the weight and volume of the produce hence lower costs in transportation and storage, although, drying alters the nutritional value of the produce e.g. loss of vitamin $\mathrm{C}$, changes in colour and appearance which might be undesirable (Ramrao, 2017).

More so, there are problems associated with open sun drying which often results in poor quality of dried commodities arising from lack of control of the drying process, possible contamination of produce by dirt, dust storms, rains, rodents, animals, infestation by insects and moulds, and possible contamination from environmental pollution etc in the traditional sun drying methods using mats and bare floors. In tropical countries like Nigeria, solar dryers can be used to dry fresh produce by harnessing the high solar intensity available for most parts of the year and this ensures better product quality and eliminates chances of probable contamination by drying the product in enclosed chambers either directly or indirectly. The enclosed chamber with a transparent cover receives direct solar heat and the heat of the sun remains trapped in the enclosure thereby enhancing the temperature of the chamber, which dries the products (Ramrao, 2017).

Orange-Fleshed Sweet potato (OFSP) is an improved breed of sweet potato (Ipomea batatas [L.] Lam) cultivated in tropical and semi-tropical regions of 
the world for food and source of income especially among the rural dwellers (Mitra, 2012). Orange flesh sweet potato has been reported to increase children's levels of vitamin A and serum retinol concentration (Ajanaku et al., 2013) and has been used to fight global vitamin A deficiency (Degras, 2003). In Nigeria, sweet potato is eaten mostly as a snack, fried, cooked, used in pounded yam, and as a sweetener in beverage production. Despite the nutritional and economic benefits of OFSP, it remains under-used in Nigeria because of its bulkiness and steady deterioration (Olubunmi et al., 2017). Hence, there is the need for conversion into other value-added forms that are less prone to deterioration.

Sweet potato roots are bulky and have a short shelf life after harvesting which makes postharvest storage difficult. Inappropriate postharvest handling practices such as poor handling, improper harvesting technique, chilling injury and extreme temperatures during storage among others are responsible for huge losses in sweet potatoes (Ashun, 2018). Drying of crops helps in reducing its bulkiness, costs of packaging, storing and transportation since the weight and volume of the final product has been reduced compared to when it is still fresh. More so, dried foods/products are less prone to chemical or enzymatic reactions that could cause alterations or spoilage due to the presence of minimum amount of water (Agarry et al., 2005). NSPRI has developed different types of solar dryers which have been used to dry some agricultural products for the purpose of improving the products' shelf life and quality (Ade et al., 2018) and have advantages over open air drying hampered by weather variability and unhygienic conditions. The different solar dryers developed by the Nigerian Stored Products Research Institute have proven to have better environmental conditions in terms of temperature and relative humidity for drying of agricultural produce. Experimental studies on the performance of the various solar tent dryers which include mobile solar tent dryers, green house solar tent dryers and parabolic solar tent dryers have been conducted using chilli pepper, yam, meat, fish, vegetables, beef meat, Chilli pepper, Telefeiria occidentalis and plantain. The Parabolic solar dryer had the highest temperature $\left(40.5 \pm 15.15^{\circ} \mathrm{C}\right)$ followed by solar tent $\left(35.72 \pm 13.67^{\circ} \mathrm{C}\right.$ ) (Ade et al., 2018). Drying was completed within different days for different crops and only \% moisture contents of the foods were evaluated. During solar drying, foods are exposed to solar radiation which in the presence of oxygen might result into loss of nutrients such as vitamins $A$ and $C$ (Kabasa et al., 2004) as well as changes in sensory quality that might not be desirable (Barrett, 2007). Drying of potatoes with NSPRI solar dryers may be a viable option to reduce postharvest loss and assist farmers to prepare a variety of potato-based food products. Hence, the study aimed to evaluate the nutritional qualities, physicochemical properties and mineral 
contents of OFSP slices dried using two NSPRI solar dryers, parabolic shaped solar tent dryer (PSTD) and brick-walled solar tent dryer (STD) for dehydration of OFSP to curb postharvest losses in fresh forms as well as achieve appreciable nutrient retention.

\section{MATERIALS AND METHODS}

Preparation of Raw Materials: Fresh Orange fleshed sweet potato roots were purchased from the Institute of Food Security, Environmental Resources and Agricultural Research, Federal University of Agriculture, Abeokuta, Ogun State, Nigeria. They were sorted and wholesome ones were washed, processed and cut into slices of average thickness, $2.32 \mathrm{~mm}$. The slices were then randomly divided into four (4) groups as fresh, sun-dried (SD), parabolic solar tent-dried (PSTD) and solar tent-dried (STD). Samples were analyzed immediately as fresh samples while some were spread on flat surfaces and dried under the sun, in parabolic shaped solar and solar tent dryer. Samples were analyzed for moisture content daily during drying for 48 hours.

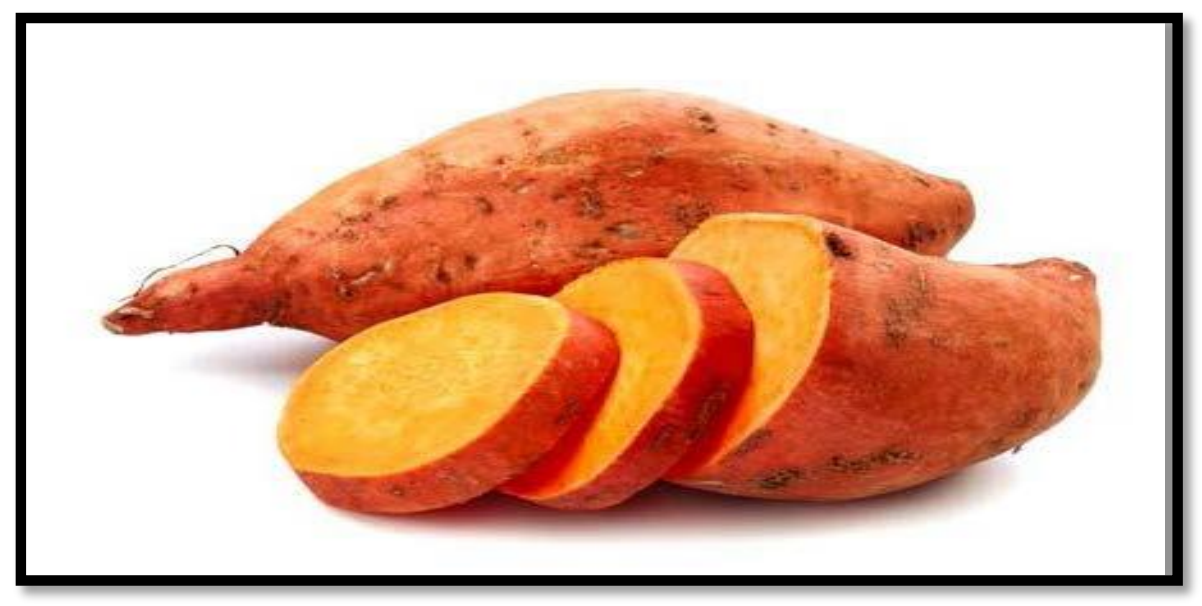

Plate 1: Fresh Orange fleshed sweet potato roots 
Orange fleshed sweet potato (OFSP) roots

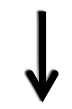

Sorting/grading

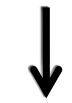

Washing

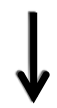

Peeling and Slicing

Parabolic solar tent dryer
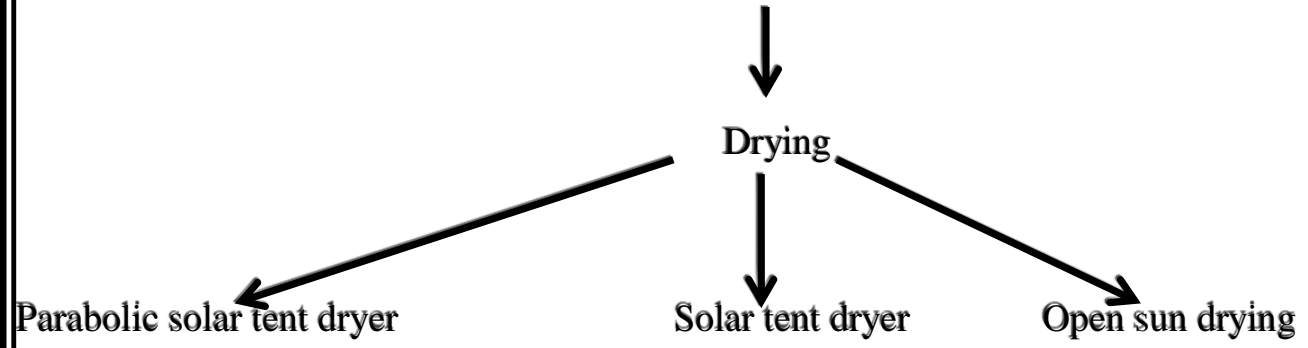

Figure 1: A flow chart showing the processing of fresh OFSP roots into dried chips

\section{Chemical Analyses}

The dried OFSP slices were analyzed for proximate composition, phytochemical properties, reducing sugar, physicochemical properties (total soluble solid, titratable acidity and $\mathrm{pH}$ ) and mineral elements. The proximate composition of dried OFSP slices was determined using Association of Official Chemists (AOAC) (2005) methods. Total carbohydrate was determined by difference. Flavonoids, phenolics, reducing sugar contents were determined by the methods of Talari et al. (2012), Makkar et al. (1999) and Megazim kit respectively, while the method of AOAC (2005) was employed for determination of mineral elements using Atomic Absorption Spectrophotometer.

\section{Statistical Analyses}

The data obtained were subjected to Variance analysis (ANOVA) and evaluated by Student Newman Kuel Test at $(p<0.05)$ using SPSS software package version 15.0.0 (IBM Statistics) for the variation between treatments. 


\section{RESULTS AND DISCUSSION}

Results showed that the average maximum and minimum temperatures during the study in parabolic-shaped solar dryer (PSSD), solar tent dryer (STD) and open sun drying (control) were $58.47^{\circ} \mathrm{C}$ and $24.63^{\circ} \mathrm{C}, 56.36^{\circ} \mathrm{C}$ and $22.89^{\circ} \mathrm{C}, 37.70^{\circ} \mathrm{C}$ and $22.49^{\circ} \mathrm{C}$ respectively. This is in line with the report by Ade et al. (2018) who stated that higher temperatures were obtained in the parabolic solar tent dryer than the solar tent dryer.

The drying temperatures obtained within the dryers are high enough to cause effective drying of crops to occur. This is an indication that the dryers will dry crops faster than the control. This corroborates the finding of Itodo et al. (2002) and Umogbai and lorter (2013) that high temperatures remove moisture faster than lower temperature. However, to prevent case hardening of the OFSP slices due to overheating during the drying, the solar dryers are adapted for increased airflows and less heat collection. No sign of spoilage due to wet interior was observed in the dried samples. In addition, the use of these dryers protects the produce against UV radiation, adverse weather conditions and contamination by animals even at night (Amit and Shrivastava, 2017).

The result of the chemical properties of Orange fleshed sweet potatoes (OFSP) dried using different drying methods is illustrated in Table 1. No significant difference was observed in ash contents of dried OFSP in all the drying methods. Fat content of dried-OFSP slices was highest in fresh samples $(7.59 \%)$ followed by sun-dried (5.0\%), ST (4.09\%) and PSTD (4.09 $\%)$. Crude fibre content of dried OFSP slices was highest in ST $(5.15 \%)$ followed by PSTD (4.80\%), SD (4.69\%) and fresh (1.93\%). The crude fibre content which is beneficial in diet of man plays an important role in decreasing many disorders such as constipation, diabetes, cardiovascular diseases and obesity. No significant difference was observed in protein content of OFSP chips that were dried with ST $(6.67 \%)$ and PSTD $(5.87 \%)$. However, protein content of fresh OFSP was highest $(9.71 \%)$ followed by SD $(8.28 \%)$ chips. Sweet potato root is normally not a major source of protein, however, proteinenriched varieties currently developed (International Life Sciences Institute, 2008) could improve the protein content of products such as chips. Odenigbo et al. (2012) reported protein values of $2.88-7.74 \%$ in french-fried sweet potato chips. The protein content of both fresh and dried OFSP obtained in this study are higher than those reported for sweet potato flour $(2.2-4.6 \%$, Fetuga et al., 2014), yam (0.9 - 1.5\%, Obadina et al., 2014) and cassava (1.2 $\%$, Balogun et al., 2012). The values of protein obtained in this study show that the fresh and dried OFSP slices meet the provision of recommended dietary allowance (RDA) of protein in the diet according to Kafatos and Hatzis (2008), which states the RDA for adults, adolescents and children as 0.8, 1.0 and $1.5 \mathrm{~g}$ protein $/ \mathrm{kg}$ body weight/day, respectively. Thus, OFSP can be used 
to improve the protein content of other root and tuber crops. Total carbohydrate was highest in fresh OFSP with no significance when compared with the SD, PSTD and ST samples. Carbohydrates are very vital in nutrition because they are good sources of energy. Oyeyinka et al. (2019) reported an average of $84 \%$ carbohydrate contents for flour from 2 cassava varieties, which is slightly higher than the highest carbohydrate (82\%) content obtained in PSTD- dried OFSP slices in this study. This confirms that root and tuber crops such as yam, cassava, potatoes are equally important compared to cereals as a global source of carbohydrates (Oladipo et al., 2017). Dry matter was lowest in fresh OFSP $(22.68 \%)$ while higher values were obtained in SD $(89.95 \%)$, PSTD $(91.89 \%)$ and ST (91.54 \%) samples but with no significant difference. Dry matter content is an important quality parameter in sweet potato production as it indicates mealiness in the boiled or roasted sweet potato and is a property most preferred by consumers (Kathabwalika et al., 2013).

Vitamin C content was highest in fresh OFSP $(67.34 \mathrm{mg} / 100 \mathrm{~g})$ and decreased significantly in SD $(11.15 \mathrm{mg} / 100 \mathrm{~g})$, PSTD $(20.49 \mathrm{mg} / 100 \mathrm{~g})$ and ST (8.55 $\mathrm{mg} / 100 \mathrm{~g}$ ). Similarly, sweet potato crisps produced with drying pre-treatment had Vitamin C content of $35.25 \mathrm{mg} / 100 \mathrm{~g}$ and $22.4 \mathrm{mg} / 100 \mathrm{~g}$ in samples without pre-treatment (Fetuga et al., 2013). These values are lower than those of fresh OFSP obtained in this study. The significant decrease in the vitamin $\mathrm{C}$ content may be due to the solubility in water, thermic destruction and enzymatic oxidation during its processing (Selman, 1994). This is similar to the reports by Kaur et al. (2002) and Takeoka et al. (2001) who stated that although tomatoes are rich source of ascorbic acid, however, processing of tomatoes has detrimental effect on their ascorbic acid retention. Phenolics contents of OFSP were not significantly different in fresh OFSP $(1.45 \mathrm{mg} / \mathrm{kg})$ and PSTD $(1.28 \mathrm{mg} / \mathrm{kg})$ as well as sun-dried $(0.86 \mathrm{mg} / \mathrm{kg})$ and STD $(0.10$ $\mathrm{mg} / \mathrm{kg}$ ). Flavonoid content of fresh OFSP was highest (339.52 mg/kg), with no significant difference between sun-dried $(132.11 \mathrm{mg} / \mathrm{kg})$ and PSTD (145.84 $\mathrm{mg} / \mathrm{kg}$ ) and low value in ST $(84.17 \mathrm{mg} / \mathrm{kg})$. This is contrary to that obtained by Kolawole et al. (2018) who reported that drying generally increased the total flavonoid content of samples of Irish potatoes, white and orange-fleshed sweet potato flour. However, Carlos et al. (2012) reported that there is decreased carotenoids, total phenolic compounds content and antioxidant activity during heat-processing methods. Thus, PSTD which is an improvement of the STD had a more favourable effect than the STD.

The reducing sugar content of OFSP slices was highest in fresh $(140.00 \mathrm{~g} / 100$ g) followed by PSTD $(82.23 \mathrm{~g} / 100 \mathrm{~g})$, SD $(65.38 \mathrm{~g} / 100 \mathrm{~g})$ and STD (35.01 $\mathrm{g} / 100 \mathrm{~g}$ ). The percentage loss in the reducing sugar content is in the order; PSTD $(12.69 \%)<$ SD $(24.73 \%)<$ STD $(74.99 \%)$. The least \% loss was 
obtained in PSTD-dried OFSP chips. According to Ade et al. (2018), the parabolic solar tent dryer has the least relative humidity among NSPRI solar tent dryers which makes it highly effective for drying high moisture crops. This may be responsible for the lower \% reduction in reducing sugar of PSTD-dried OFSP slices than in those dried in STD. The high sugar content of both fresh and dried OFSP chips may be responsible for its use as sweetener in drinks and local beverages like 'kunu'.

Table 1: Effect of drying using parabolic solar tent, solar tent dryer and open sun drying on the proximate composition of OFSP dried chips (\%)

\begin{tabular}{lllllll}
\hline Sample & Ash & Fat & $\begin{array}{l}\text { Crude } \\
\text { Fibre }\end{array}$ & Protein & $\begin{array}{l}\text { Carbo- } \\
\text { hydrates }\end{array}$ & $\begin{array}{l}\text { Dry } \\
\text { matter }\end{array}$ \\
\hline $\begin{array}{l}\text { Fresh } \\
\text { OFSP }\end{array}$ & $4.15^{\mathrm{ab} \pm .29}$ & $7.59^{\mathrm{c}} \pm 0.41$ & $1.93^{\mathrm{a}} \pm 0.14$ & $9.71^{\mathrm{b}} \pm 0.31$ & $74.06^{\mathrm{a}} \pm 1.94$ & $22.68^{\mathrm{a}} \pm 0.26$ \\
$\begin{array}{l}\text { OAD- } \\
\text { dried } \\
\text { OFSP }\end{array}$ & $3.69^{\mathrm{a}} \pm 0.11$ & $5.09^{\mathrm{b}} \pm 0.08$ & $4.69^{\mathrm{b}} \pm 0.47$ & $8.28^{\mathrm{b} \pm 0.23}$ & $78.22^{\mathrm{b}} \pm 0.93$ & $89.95^{\mathrm{b}} \pm 0.22$ \\
$\begin{array}{l}\text { PSTD- } \\
\text { OFSP }\end{array}$ & $3.76^{\mathrm{ab} \pm 0.97}$ & $4.09^{\mathrm{a}} \pm 0.02$ & $4.80^{\mathrm{b}} \pm 0.35$ & $5.87^{\mathrm{a}} \pm 0.78$ & $82.21^{\mathrm{b}} \pm 0.43$ & $91.89^{\mathrm{b}} \pm 0.13$ \\
$\begin{array}{l}\text { STD- } \\
\text { OFSP }\end{array}$ & $4.09^{\mathrm{a}} \pm 0.32$ & $4.09^{\mathrm{a}} \pm 0.63$ & $5.15^{\mathrm{c}} \pm 0.18$ & $6.67^{\mathrm{a}} \pm 0.73$ & $80.00^{\mathrm{b}} \pm 0.40$ & $91.54^{\mathrm{b}} \pm 0.35$ \\
\hline
\end{tabular}

OAD-OFSP: Open air-dried orange fleshed sweet potato; PSTD-OFSP:

Parabolic shaped solar tent dryer orange fleshed sweet potato; STD-OFSP:

Solar tent dried orange fleshed sweet potato. Values are represented on \% dry weight basis. Values are represented as Mean \pm SEM. Values with various superscripts along the column are significantly different $(p \leq 0.05)$. 
Table 2: Effect of drying using parabolic solar tent, solar tent dryer and open sun drying on the quality attributes of OFSP dried chips

\begin{tabular}{lllll}
\hline Sample & $\begin{array}{l}\text { Vitamin C } \\
(\mathrm{mg} / 100 \mathrm{~g})\end{array}$ & $\begin{array}{l}\text { Phenolics } \\
(\mathrm{mg} / \mathrm{kg})\end{array}$ & $\begin{array}{l}\text { Flavonoids } \\
(\mathrm{mg} / \mathrm{kg})\end{array}$ & $\begin{array}{l}\text { Reducing sugar } \\
(\mathrm{g} / 100 \mathrm{~g})\end{array}$ \\
\hline Fresh OFSP & $67.34^{\mathrm{c}} \pm 11.22$ & $1.45^{\mathrm{b}} \pm 0.01$ & $339.52^{\mathrm{d}} \pm 4.42$ & $140.00^{\mathrm{d}} \pm 0.86$ \\
OAD-dried OFSP & $11.15^{\mathrm{a}} \pm 0.49$ & $0.86^{\mathrm{a}} \pm 0.00$ & $132.11^{\mathrm{bc} \pm 5.41}$ & $65.38^{\mathrm{b}} \pm 1.89$ \\
PSTD-OFSP & $20.49^{\mathrm{b}} \pm 3.41$ & $1.28^{\mathrm{b}} \pm 0.00$ & $145.84^{\mathrm{c}} \pm 3.93$ & $82.23^{\mathrm{c}} \pm 2.59$ \\
STD-OFSP & $8.552^{\mathrm{a}} \pm 9.54$ & $0.10^{\mathrm{a}} \pm 0.00$ & $84.17^{\mathrm{a}} \pm 7.92$ & $35.01^{\mathrm{a}} \pm 33.56$
\end{tabular}

OAD-OFSP: Open air-dried orange fleshed sweet potato; PSTD-OFSP: Parabolic shaped solar tent dryer orange fleshed sweet potato; STD-OFSP: Solar tent dried orange fleshed sweet potato. Values are represented on \% dry weight basis. Values are represented as Mean \pm SEM. Values with various superscripts along the column are significantly different $(p \leq 0.05)$.

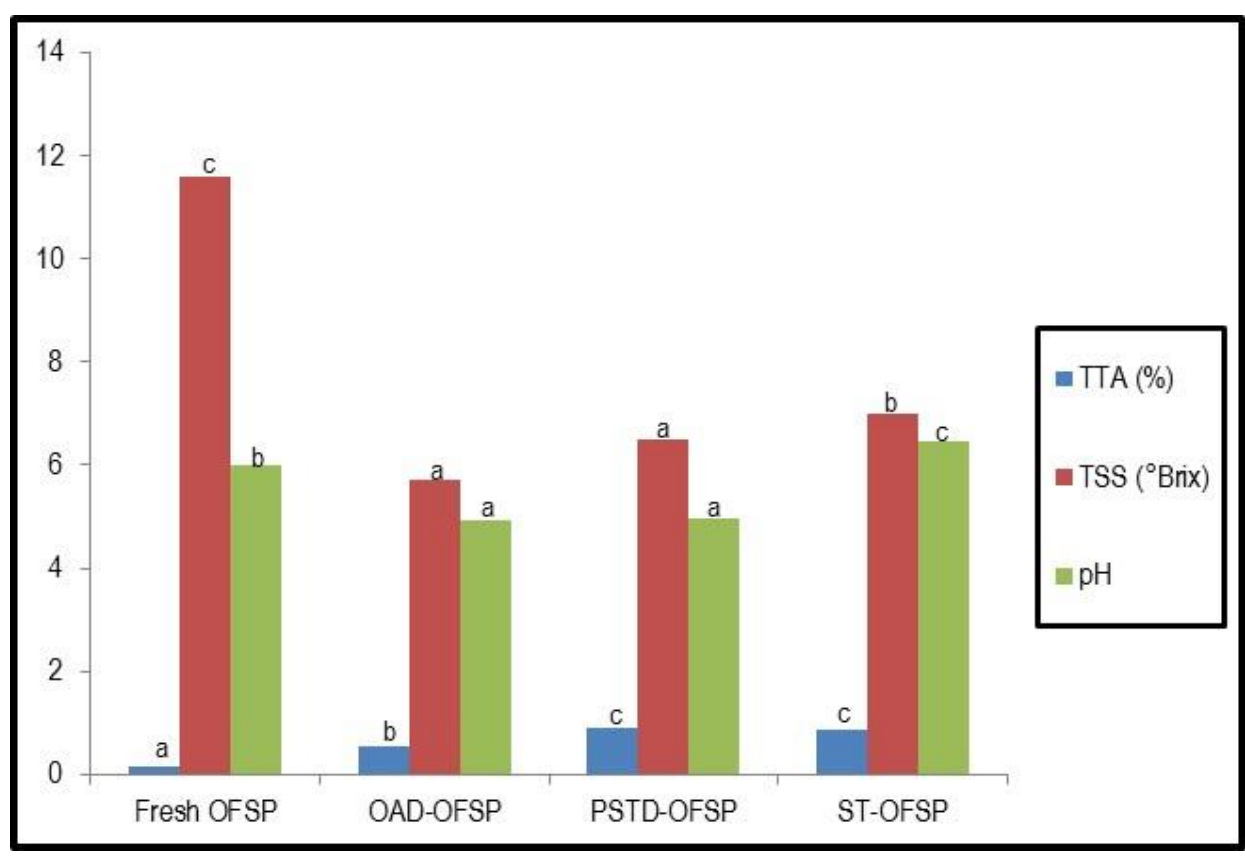

Figure 2: Effect of Drying using Parabolic solar tent, Solar tent dryer and Open sun drying on the Physico-chemical properties of OFSP dried Chips. Bars with similar colour with different alphabelts are significantly different $(p=0.05)$. OAD-OFSP: Open air-dried orange fleshed sweet potato; PSTD-OFSP: Parabolic shaped solar tent dryer orange fleshed sweet potato; STD-OFSP: Solar tent dried orange fleshed sweet potato. 
Table 3: Mineral constituents of OFSP chips dried using parabolic solar tent, solar tent dryers and open sun drying

\begin{tabular}{|c|c|c|c|c|}
\hline & \multicolumn{4}{|c|}{ Samples } \\
\hline $\begin{array}{l}\text { Minerals } \\
(\mathrm{ppm})\end{array}$ & Fresh OFSP & OAD-OFSP & PSTD-OFSP & STD-OFSP \\
\hline Zinc (Zn) & $0.09 a \pm 0.03$ & $0.035^{c} \pm 0.00$ & $0.06^{b} \pm 0.01$ & $0.017^{d} \pm 0.00$ \\
\hline Magnesium (Mg) & $2.26^{b} \pm 0.01$ & $2.08^{d} \pm 0.01$ & $2.11^{\mathrm{c}} \pm 0.01$ & $2.56^{\mathrm{a}} \pm 0.01$ \\
\hline Potassium (K) & $5.14 \pm 0.01^{d}$ & $5.55^{b} \pm 0.01$ & $5.47^{c} \pm 0.01$ & $5.84^{a} \pm 0.01$ \\
\hline Calcium (Ca) & $8.78^{d} \pm 0.01$ & $9.52^{b} \pm 0.01$ & $9.38^{c} \pm 0.01$ & $13.11^{a} \pm 0.01$ \\
\hline Aluminum (Al) & Nil & Nil & Nil & Nil \\
\hline Sodium $(\mathrm{Na})$ & $8.40^{d} \pm 0.00$ & $25.21^{a} \pm 0.01$ & $13.96^{c} \pm 0.01$ & $23.75^{b} \pm 0.29$ \\
\hline Iron $(\mathrm{Fe})$ & $2.11^{b} \pm 0.01$ & $2.17^{b} \pm 0.01$ & $2.18^{b} \pm 0.00$ & $2.29^{a} \pm 0.01$ \\
\hline Lead $(\mathrm{Pb})$ & Nil & 0.00 & Nil & 0.00 \\
\hline Chromium (Cr) & $0.14^{c} \pm 0.00$ & $0.16^{a} \pm 0.00$ & $0.09^{d} \pm 0.01$ & $0.15 \pm 0.00$ \\
\hline Manganese (Mn) & $0.10^{a} \pm 0.00$ & $0.09^{a b} \pm 0.01$ & $0.10^{c} \pm 0.01$ & $0.077^{c} \pm 0.00$ \\
\hline Cadmium (Cd) & Nil & Nil & Nil & Nil \\
\hline
\end{tabular}

OAD-OFSP: Open air-dried orange fleshed sweet potato; PSTD-OFSP: Parabolic shaped solar tent dryer orange fleshed sweet potato; STD-OFSP: Solar tent dried orange fleshed sweet potato. Values are represented on \% dry weight basis. Values are represented as Mean \pm SEM. Values with various superscripts along the column are significantly different $(p \leq 0.05)$.

The effect of drying on the physicochemical properties of OFSP chips using the parabolic solar tent dryer, solar tent dryer and open sun drying is shown in Figure 2. The least titratable acidity value was found in fresh OFSP $(0.17$ $\%)$ and highest in PSTD-OFSP $(0.89 \%)$ and ST-OFSP $(0.88 \%)$. The least total soluble solid (TSS) was found in OAD-OFSP $\left(5.70{ }^{\circ} \mathrm{Brix}\right)$, followed by PSTD-OFSP (6.50 $\left.{ }^{\circ} \mathrm{Brix}\right)$, ST-OFSP (7.00 $\left.{ }^{\circ} \mathrm{Brix}\right)$ and highest in fresh OFSP (11.60 ${ }^{\circ} \mathrm{Brix}$ ) while $\mathrm{pH}$ values ranged from 4.94 to 6.47 in all the groups. The 'Brix concentration of TSS was highest in fresh OFSP followed by PSTD dried OFSP chips and this is similar to the trend of reducing sugar content obtained in fresh OFSP as well as PSTD dried OFSP chips. The reduction in $\mathrm{pH}$ in dried OFSP samples can be attributed to concentration of organic acids with removal of water (Hii et al., 2009; Afolabi et al., 2011). This offers protection against microbial growth and thus extends shelf life of dried foods due to concentrated organic acids and low moisture content. However, the slight increase in $\mathrm{pH}$ in ST-dried OFSP may be due to reabsorption of moisture during handling. Aluminum, lead and cadmium were not found in fresh and all the dried OFSP with high levels of potassium, calcium and sodium in all the groups of OFSP. The presence of the minerals in OFSP slices in this study 
may be due to the level of minerals in the soil where it was grown and the variety. More so, the absence of toxic minerals as reported in this study may be because the environment where the OFSP was grown is free from toxic minerals.

\section{CONCLUSION}

OFSP slices dried using the parabolic solar tent dryer had higher vitamin C, phenolics, flavonoids and reducing sugar contents than that obtained using STD next to the fresh OFSP. Hence, the use of NSPRI parabolic shaped solar tent dryer is recommended for farmers and agro-processors in the processing of OFSP as a postharvest technology for reduction of losses and solution to problems associated with storage of fresh roots.

\section{REFERENCES}

Ade, A. R., Olayemi, F. F, Adebiyi, A. O., Zubair, O. M., Adeiza, O. A., and Achime, K. C. (2018). Recent Advances in Solar Drying of Agricultural Produce in Nigeria-NSPRI Experience. Arid Zone Journal of Engineering, Technology \& Environment, 14(SP. i4), 86-94.

Afolabi, I. S., Marcus, G. D., Teminijesu, O. O. and Chizea, V. (2011). Biochemical effect of some food processing methods on the health promoting properties of under-utilized Carica papaya. Journal of Natural Products, 4, 17-24.

Agarry, S. E., Durojaiye, A. O. and Afolabi, T. J. (2005). Effects of Pretreatment on the Drying Rates and Drying Time of Potato. Journal of Food Technology, 3 (3), 361-364.

Ajanaku, K. O., Ajani, O., Siyanbola, T. O., Akinsiku, A. A., Ajanaku, C. O., and Oluwole, O. (2013). Dietary Fortification of Sorghum Ogi Using Crayfish. Food Science and Quality Management,15, 1-9.

Amit, K., and Shrivastava, V. (2017). Historical Trends and Recent Developments in Solar Greenhouse Dryer Operated Under Active Mode: A Review. Indian Journal of Science and Technology, 10(33), 101112.

Ashun, E. K. (2018). Orange Fleshed Sweet Potato: Its use in Complementary Infant Formula. An unpublished M.Sc. thesis submitted to the Department of Vocational and Technical Education of the Faculty of Science and Technology Education, College of Education Studies, University of Cape Coast.

Association of Official Analytical Chemists (AOAC) (2005). Official Methods of Analysis. (18th ed.) Washington D.C., USA.

Balogun, M. A., Karim, O. R., Kolawole, F. L. and Solarin, A. O. (2012). Quality Attributes of Tapioca Meal Fortified with Defatted Soy Flour. Agrosearch, 12(1), $61-67$. 
Barrett, D. M. (2007). Maximizing the nutritional value of fruits and vegetables. Journal of Food Technology, 61(4), 40 - 44.

Carlos, M. D., Jocelem, M., Alessandro, O. R., Priscila, R. S. and André, J. (2012). Stability of carotenoids, total phenolics and in vitro antioxidant capacity in the thermal processing of orange-fleshed sweet potato (Ipomoea batatas Lam.) cultivars grown in Brazil. Plant Foods Human Nutrition, 67, 262-270.

Commercial Cooperation of the Organization of the Islamic Cooperation (COMCEC) (2019). 14th Islamic Summit, Makkah Al-Mukarramah, May 31st, 2019 COMCEC Coordination Office.

Degras, L. (2003). Sweet Potato. Macmillan, Oxford. England.

Fetuga, G., Tomlins, K., Henshaw, F.,and Idowu, M. (2014). Effect of variety and processing method on functional properties of traditional sweet potato flour (elubo) and sensory acceptability of cooked paste (amala). Food Science Nutrition, 2. 682-684.

Fetuga, G. O., Odulaja, A. O., and Adelekan, A. O. (2013). Composition and Sensory Quality of Sweet Potato Crisps as Influenced by Pre-frying Treatment. Journal of Natural Science, Engineering and Technology, 12(1), 99-107.

Hii, C. L., Law, C. L., Cloke, M. and Suzannah, S. (2009). Thin layer drying kinetics of cocoa and dried product quality. Biosystems Engineering 102(2), 153 - 161.

International Life Sciences Institute (ILSI). (2008). Nutritionally improved sweet potato. In: Assessment of foods and feeds. Comprehensive Reviews in Food science and Food safety, 7(1), 81-91.

Itodo, I. N., Obetta, S. E. and Satimehin, A. A. (2002). Evaluation of a solar tent dryer for rural applications in Nigeria. Botswana Journal of Technology, 11 (2), 58-62.

Kabasa, J. D., Ndawula, J., and Byaruhanga, Y. B. (2004). Alterations in fruit and vegetable $\beta$-carotene and vitamin $C$ content caused by open-sun drying, visqueen-covered and polyethylene-covered, solar-dryers. African Health Sciences, 4(2), 125 - 130.

Kafatos, A. and Hatzis, C. (2008). Clinical nutrition for medical students. University of Crete, Rethimno, Greece.

Kathabwalika, D. M., Chilembwe, E. H. C., Mwale, V. M., Kambewa, D., and Njoloma, J. P. (2013). Plant growth and yield stability of orange fleshed sweet potato (Ipomoea batatas) genotypes in three agro-ecological zones of Malawi. International Research Journal of Agricultural Science and Soil Sciences, 3(11), 383-392. 
Kaur, R., Savage, G. P., and Dutta, P. C. (2002). Antioxidant vitamins in four commercially grown tomato cultivars. Proceedings of the Nutrition Society of New Zealand.

Kolawole, F. L., Balogun, M. A., Akeem, S. A., and Salaudeen, S. A. (2018). Effect of drying methods on the yield, phytochemical composition and antioxidant activities of potato (Solanum tuberosum) and two sweet potato (Ipomoea batatas) varieties. Carpathian Journal of Food Science and Technology, 10 (2),107-119.

Makkar, H. P. S. (1999). Quantification of tannins in tree foliage. A laboratory manual for $\mathrm{FAO} / \mathrm{IAEA}$.

Mitra, S. (2012). Nutritional Status of Orange-Fleshed Sweet Potatoes in Alleviating Vitamin A Malnutrition through a Food-Based Approach. Journal of Nutrition Food Science, 2(8), 1-3.

Morris, A., Barnett, A., and Burrows, O. (2004). Effect of processing on nutrient content of foods. Cajarticles, 37, 160-164.

Naziri, D., Quaye, W., Siwoku, B., Wanlapatit, S., Tu Viet, P., and Bennett, B. (2015). The diversity of postharvest losses in cassava value chains in selected developing countries. Journal of Agriculture and Rural Development in the Tropics and Subtropics, 115, 111-123.

Obadina, A. O., Babatunde, B. O., and Olotu, I. (2014). Changes in nutritional composition, functional, and sensory properties of yam flour as a result of pre-soaking. Food Science Nutrition, 2, 676-681.

Odenigbo, A., Rahimi, J., Ngadi M., Amer, S., and Mustafa, A. (2012). Starch digestibility and predicted glycemic index of fried sweet potato cultivars. Functional Foods in Health and Disease, 2 (7), 280- 289.

Oguntade, A. E. (2013). Food losses in cassava and maize value chains in Nigeria: Analysis and recommendations for reduction strategies. Published by Deutsche Gesellschaft für Internationale Zusammenarbeit (GIZ) $\mathrm{GmbH}$.

Oladipo, F. O., Bolarin, O., Daudu, A. K., Kayode, A. O, and Awoyele, P. O. (2017). Utilization of Soil Conservation Practices among Root and Tuber Farmers in Oyun Local Government Area of Kwara State, Nigeria. Agrosearch, 17 (2), 99- 109.

Olubunmi, A. A., Abraham, I. O., Mojirade, L. A., Afolake, O. B., and Kehinde, O. E. (2017). Development, Evaluation and Sensory Quality of Orange Fleshed Sweet Potato (Ipomoea batatas Lam) Extruded Pasta Products. Croatian Journal of Food Technology, Biotechnology and Nutrition, 12 (1-2), 83-89.

Oyeyinka, S. A., Adeloye, A. A.., Smith, S. A., Adesina, B. O., and Akinwande, F. F. (2019). Physicochemical Properties of Flour and Starch from Two Cassava Varieties. Agrosearch, 19(1): 28-45. 
Ramrao, R. N. (2017). Solar dryer. International Journal of Advance Research and Innovative Ideas in Education, 5 (3), 2395-4396.

Selman, I. D. (1994). Vitamin retention during blanching of vegetables. Food Chemistry, 49, 1437-1474.

Talari, S., Rudroju, S., Penchala, S. and Nanna-Rama, S. (2012). Quantification of total phenolics and total flavonoids contents in extracts of Oroxylum indicum I. Kurz. Asian Journal Pharmacology Clinical Research, 5(4), 177-179.

Takeoka, G. R., Dao, L., Fless, S., Gillespie, D. M., Jewell, W. T., and Huebner, B. (2001). Processing effects on lycopene content and antioxidant activity of tomatoes. Journal of Agricultural and Food Chemistry, 49 3713.

Umogbai, V.I and lorter, H.A (2013). Design, construction and performance evaluation of a passive solar dryer for maize cobs. African Journal of Food Science and Technology, 4 (5), 110-115. 